\title{
Sexual behaviour and infection rates for HIV, blood-borne and sexually transmitted infections among patients attending drug . treatment centres in Rio de Janeiro, Brazil
}

\author{
F I Bastos $\mathrm{MD} \mathrm{PhD}^{1}, \mathrm{C}$ M Lowndes $\mathrm{PhD}^{2}, \mathrm{M}$ Derrico $\mathrm{BS}^{1}$, L R Castello- \\ Branco $\mathrm{MD} \mathrm{PhD}^{3}, \mathrm{M}$ I Linhares-de-Carvalho $\mathrm{MD}^{4}, \mathrm{~W}$ Oelemann $\mathrm{PhD}^{5}$, \\ F Bernier $\mathrm{MSc}^{6}$, M G Morgado $\mathrm{PhD}^{3}, \mathrm{C} \mathrm{F}$ Yoshida $\mathrm{PhD}^{7}$, \\ T Rozental $\mathrm{BSc}^{7}$ and $\mathrm{M}$ Alary $\mathrm{MD} \mathrm{PhD}^{2}$ \\ ${ }^{1}$ Department of Health Information (DIS/CICT), ${ }^{3}$ Department of Immunology and \\ Molecular Biology (IOC) and ${ }^{7}$ Department of Virology (IOC) and the Brazilian Reference \\ Centre for Viral Hepatitis, Oswaldo Cruz Foundation, Rio de Janeiro, Brazil, ${ }^{2}$ Epidemiology \\ Research Group, Department of Social and Preventive Medicine, Laval University, Québec, \\ Canada, ${ }^{4}$ Ambulatório do Banco da Providência, Rio de Janeiro, Brazil, ${ }^{5}$ Department of \\ Microbiology, Federal University of Rio de Janeiro, Rio de Janeiro, Brazil and ${ }^{6}$ Department \\ of Microbiology and Immunology, University of Montreal, Montreal, Canada
}

\begin{abstract}
Summary: A survey was carried out in 2 drug use treatment centres (TCs) in Rio de Janeiro, Brazil, to assess risk behaviours, HIV infection and other sexually transmitted infections/blood-borne infections (STIs/BBIs). Two hundred and twenty-five drug users (195 males and 30 females) were interviewed and clinically examined, and their blood and urine were tested for STIs/BBIs. Prevalences (\%) for these infections were as follows - HIV: 0.9, hepatitis B virus (HBV): 14.7, hepatitis C virus (HCV): 5.8, syphilis: 5.3 , gonorrhoea/chlamydia $(\mathrm{CT} / \mathrm{NG}): 4.7$. In bivariate analyses $\mathrm{CT} / \mathrm{NG}$ infection was associated with younger age $(P=0.003)$; current genitourinary symptoms (odds ratio $[\mathrm{OR}]=6.2$ ) and a mainly illegal source of income $(\mathrm{OR}=9.1)$. Hepatitis $\mathrm{C}$ infection was associated with a history of ever having injected any drug (OR=19.6), and with each one of the injected drugs. After multiple logistic regression, lower educational level (adjusted odds ratio $[A O R]=3.70$ ) and 'ever having injected drugs' ( $\mathrm{AOR}=3.69)$ remained as independent risk factors for hepatitis $B$ infection. In conclusion, TCs must implement programmes directed towards the prevention of STIs/BBIs.
\end{abstract}

Keywords: Drug users, HIV infection, sexually transmitted infections, viral hepatitis, drug treatment centres

\section{INTRODUCTION}

The AIDS epidemic has functioned as a stimulus for carrying out studies among drug users in Brazil, mostly implemented in the south-east and north-east (Bahia State) regions of the country1. In addition to HIV infection rates, data are now available on syphilis, human T-cell lymphotrophic virus (HTLV)-I/II and viral hepatitis (B and C) infection in a sample of street-recruited injecting drug users (IDUs) in Santos, São Paulo; viral

Correspondence to: Francisco Inácio Bastos, Departamento de Informações para a Saúde (DIS/CICT), Fundação Oswaldo Cruz. Biblioteca de Manguinhos suite 209, Av. Brasil 4365, Rio de Janeiro 21045-900, Brazil hepatitis in a sample of IDUs in Rio de Janeiro'; and HTLV-I/II in IDUs in Salvador, Bahia ${ }^{4-6}$. More recently, other studies have addressed HIV/AIDS in different drug-using populations, such as crack cocaine consuming commercial sex workers ${ }^{7}$ and imprisoned drug users ${ }^{8}$. To date, however, no studies have been carried out which target sexual behaviour among drug users in Brazil, or on infection rates with diseases transmitted exclusively by sexual contact, despite the now wellrecognized links between drug use and risky sexual behaviour, particularly prostitution and crack cocaine use?

The present paper reports data from a research and prevention project carried out in Rio de Janeiro, Brazil, during the first semester 
of 1998. The aim of the project was to assess infection rates for HIV, viral hepatitis and other STIs (chlamydia, gonorrhoea and syphilis), and to counsel and treat inpatients attending drug abuse facilities in Rio. The data presented here are part of an ongoing project targeting drug users both in 'drug scenes' and drug treatment settings, with research and prevention components. A second phase will specifically target IDUs, and crack cocaine users in 'street' settings as opposed to treatment settings.

Former analyses have shown that the evaluation and prevention of HIV/AIDS and STDs are seldom if ever addressed by drug treatment centres' staff in Rio de Janeiro ${ }^{10}$, which highlight the need to carry out studies and preventive interventions in such environments.

\section{METHODS}

\section{Study population}

The study was carried out in 2 drug treatment centres in Rio de Janeiro city. Centre 1 is, as far as we know, the biggest public drug treatment centre in Latin America, with 60 beds, and is located in the western zone of Rio. A semi-public institution, it essentially caters for people from lower-middle and working-class strata, insured through the staterun National Health Insurance system. Centre 2 is a facility with 20 beds, located in the southern, richer area of Rio, which essentially caters for patients insured by private health insurance plans as well as paying clients. In order to increase the number of women assessed (who are quite few in numbers in both centres, and also generally uncommon in the Rio de Janeiro drug scene ${ }^{11}$ ), we also made one visit to a therapeutic community for women located on a ranch far outside the city; but even there we found only 5 women.

Such centres are the largest inpatient facilities devoted exclusively to the treatment of drug users in Rio de Janeiro in operation when the project was implemented, and are broadly representative of a very heterogeneous group of small centres scattered all over the city.

\section{Data and sample collection}

A few days before the monthly visit by the project's 'mobile team', the field coordinator contacted all the inpatients at each facility to explain the project's aims and procedures. Almost all the patients contacted immediately agreed to attend the various phases of the evaluation: (a) to answer a questionnaire on sociodemography, drug and alcohol consumption patterns and injecting and sexual risk behaviours, after signing an informed consent form; (b) to donate $30 \mathrm{ml}$ of blood and a urine sample (around $30 \mathrm{ml}$ ); and (c) to be clinically examined on the day of the monthly visit. As a check for data integrity, questionnaires and clinical report forms - which were completed by a second team of independent observers-contained a common section addressing basic sociodemographic characteristics.

Due to the philosophy of the centres, no individual compensation for time and effort was given to study participants. However, free and immediate access, with transportation, to dental treatment, general clinical care and medication, if necessary, as well as broad psychological support (whether related to drug use or not), was offered to all inpatients, whether or not they participated in the study.

During the monthly visit the project team coordinated a focus group debate, addressing prevention of HIV/AIDS and other BBIs and STIS. The team also offered contact phone numbers and/ or further referrals. Each patient was also given the opportunity to approach members of the project team for counselling on an individual basis. Meanwhile, the patients were directed to one of the 2 physicians on the mobile team with expertise in STDs for an on-site clinical examination.

Questionnaires were applied by previously trained interviewers. Although urine collection presented no difficulty, blood collection was sometimes a challenge: most inmates with previous experiences of injection drug use were reluctant to donate blood since needles reminded them of their former injecting experiences; other drug users were afraid their blood might be tested for traces of illegal drugs (which they did not associate with the urine samples); others were simply afraid to donate blood because of a perceived risk of getting HIV/AIDS due to the supposed use of non-sterile needles (an idea with no objective basis in urban Brazilian settings). Due to these considerable difficulties with blood sample collection, commonly encountered by those working in this field in Brazil and elsewhere, the project also included an evaluation of a urine HIV-1 enzyme immunoassay (EIA) test kit (Calypte Biomedical Corporation), for potential use as an alternative to serum testing in future surveys on drug users, especially IDUs.

Due to the nature of the study sites (which were abstinence oriented, both from drugs and sex, although the latter only while actually at the treatment centre), no condoms were provided during the site visits, although they were distributed to patients on their release from the centres at the discretion of the field coordinator, with further referral to a 'harm-reduction' oriented assessment centre located in downtown Rio.

A code was given to each patient, to be used at their discretion at the referral facilities (although most preferred always to use their names), and to receive laboratory results on an individual basis from the field coordinator, with further counselling. Only the field coordinator and the Project principal investigator (PI) had access to these codes and all the analyses were carried out on an exclusively aggregate basis. 


\section{Laboratory and data analysis}

Due to the fact that the project included as one of its components the evaluation of a urine HIV-1 EIA kit, the algorithm for HIV testing was more detailed than in the usual Brazilian consensual procedures. Urine samples were sent to the Department of Microbiology (UFRJ, Rio de Janeiro) for HIV analysis, and stored at $-20^{\circ} \mathrm{C}$ for Neisseria gonorrhoeae (NG) and, Chlamydia trachomatis $(\mathrm{CT})$ testing. Blood samples were also initially analysed for HIV in the same laboratory, using 2 enzyme-linked immunosorbent assay (ELISA) tests with different specifications. All previously positive results on blood or urine ELISA tests were confirmed by Western blot analyses (Cambridge Biotech Co., Worcester, MA, USA), performed in 2 independent laboratories (Microbiology/UFRJ and Department of Immunology, FIOCRUZ, Rio de Janeiro).

Urine samples, stored at $-20^{\circ} \mathrm{C}$, were sent to the Department of Microbiology and Immunology, Montreal University, where they were analysed by polymerase chain reaction (PCR), using the Amplicor ${ }^{\mathrm{TM}} \mathrm{CT} / \mathrm{NG}$ dual detection kit (Roche Diagnostics). The results for $\mathrm{CT} / \mathrm{NG}$ infection are available for 192 out of the 225 study participants. Blood samples were tested for syphilis using the standard Venereal Disease Research Laboratory (VDRL) test, with further confirmation by Treponema pallidum haemagglutination assay (TPHA).

Viral hepatitis serology was carried out at the National Reference Centre for Viral Hepatitis, Department of Virology/IOC, FIOCRUZ. All sera samples were tested for HBsAg (Hepanostika HBsAg Uniform II kit, Organon Teknika), anti$\mathrm{HBC}$ (Hepanostika anti-HBc Uniform kit, Organon Teknika), and anti-HCV (UBI HCV EIA 4.0, Organon Teknika), using EIA. In addition, antiHBs (Hepanostika anti-HBs Uniform kit, Organon Teknika), and HCV-RNA detection were performed on anti-HBc and anti-HCV positive samples, respectively. Past $\mathrm{HBV}$ infection was defined by the presence of anti-HBc and anti$\mathrm{HBs}$, and current infection by the presence of HBsAg. HCV infection was defined by the presence of anti-HCV antibodies and further HCV RNA detection. RNA extraction and RTPCR for HCV 5'UTR (5' untranslated region) amplification were performed as previously described ${ }^{12}$.

Data were entered in Epi-info ${ }^{13}$, and analysed using the SAS statistical package ${ }^{14}$. Bivariate analysis used were: the Chi-square or Fisher's exact tests for dichotomous variables; the MantelHaenszel Chi-square test for trend for categorical variables with more than 2 categories; and the Kruskal-Wallis test for means (Chi-square approximation) for continuous variables. Further analysis using multiple logistic regression was performed for risk factors associated with hepatitis B infection.

\section{RESULTS}

After the group debate and individual counselling, almost all the patients agreed to donate blood, and only 4 patients were excluded from the final analysis because blood samples were not collected.

Main sociodemographic findings and patterns of drug and alcohol consumption are presented in Table 1 . The patients were generally male, in their early thirties, and with an educational level (especially the women) which was relatively high by Brazilian standards ${ }^{15}$. Over $60 \%$ of the interviewees were single, and a slightly lower proportion of the interviewees from both sexes $(49-57 \%$, men and women, respectively) had no stable partner. Among those with a stable partner, the proportion of men co-habiting with their sexual partners was significantly higher than that for women $(P=0.016)$.

Overall, over half of the interviewees (57\%) had been imprisoned at least once, but the figures were significantly higher for men than for women $(P=0.009)$. A significant proportion of the interviewees (around 14\%) of both sexes were engaged in illegal activities that provided for their daily needs, and over $42 \%$ of the interviewees had no regular source of income - a high proportion, even given current levels of (formal) unemployment in Rio de Janeiro ${ }^{16}$.

Since the sample included people from 2 treatment centres, with quite different characteristics, ranges for 'monthly income' comprised people who could be included in Brazilian low class (2-10 minimum salaries [MS]) and 'standard' middle class (over $10 \mathrm{MS}$ ) categories, as well as people eaming less than $2 \mathrm{MS}$, which defined them as belonging to the Brazilian lower social strata. Statistically significant differences $(P<0.05)$ between the patients in the 2 centres were seen in socioeconomic indicators, including educational level, regular employment, monthly income and history of imprisonment. However, apart from lifetime history of STDs, no significant differences were seen in sexual risk behaviours, drug consumption patterns and inpatients' medical histories.

As shown in Table 2, roughly one-third of the patients had been previously treated for drug and/ or alcohol consumption.

Figures for recent injection drug use were quite low (1-3\%), while 24 patients (roughly $10 \%$ of the sample) reported ever having injected drugs, with the most commonly injected drug being cocaine. Heroin use, which has been virtually absent from the Brazilian drug scene in the last decades ${ }^{17}$, was reported by 7 patients, but none of them had injected it.

Most of the people were polydrug users, with high levels of consumption of powder cocaine, marijuana, and alcohol, the latter being assessed by the inclusion in the questionnaire of a brief instrument (the CAGE test ${ }^{18}$ ). Eighteen per cent of 
Table 1. Sociodemographic characteristics of the sample: drug users from inpatient units, Rio de Janeiro 1998

\begin{tabular}{|c|c|c|c|}
\hline Variables & $\begin{array}{l}\text { All }(n=225) \\
n(\%)\end{array}$ & $\begin{array}{l}\operatorname{Men}(n=195) \\
n(\%)\end{array}$ & $\begin{array}{l}\text { Women } \\
(n=30) \\
n(\%)\end{array}$ \\
\hline Mean $[ \pm S D]$ age in years & $32.1[9.5]$ & $32.3[9.3]$ & $31.5[11.0]$ \\
\hline Median & 31.0 & 31.0 & 29.5 \\
\hline Range & $15-61$ & $16-61$ & $15-56$ \\
\hline \multicolumn{4}{|l|}{ Education } \\
\hline Up to 8 years of formal education & $103(45.8)$ & $93(47.7)$ & $10(33.3)$ \\
\hline 8 years/more of formal education & $122(54.2)$ & $102(52.3)$ & $20(66.6)$ \\
\hline \multicolumn{4}{|l|}{ Marital status (official) } \\
\hline Single & $137(60.9)$ & $118(60.5)$ & $19(63.3)$ \\
\hline Married & $67(29.8)$ & $62(31.8)$ & $5(16.7)$ \\
\hline Divorced/widowed & $21(9.3)$ & $15(7.7)$ & $6(20.0)$ \\
\hline \multicolumn{4}{|l|}{ Stable sex partner } \\
\hline Co-habiting & $65(28.9)$ & $62(31.8)^{*}$ & $3(\mathbf{1 0 . 0})^{*}$ \\
\hline Not co-habiting & $47(20.9)$ & $37(19.0)$ & $10(33.3)$ \\
\hline No stable partner & $113(50.2)$ & $96(49.2)$ & $17(56.7)$ \\
\hline Ever imprisoned/in jail & $128(56.9)$ & $118(60.5)^{\dagger}$ & $10(33.3)^{\dagger}$ \\
\hline \multicolumn{4}{|l|}{ Source of income } \\
\hline In regular employment & $97(43.1)$ & $86(44.1)$ & $11(36.7)$ \\
\hline No regular income & $96(42.7)$ & $82(42.1)$ & $14(46.6)$ \\
\hline Illegal (prostitution, drug-dealing, etc.) & $32(14.2)$ & $27(13.8)$ & $5(16.7)$ \\
\hline \multicolumn{4}{|l|}{ Monthly income } \\
\hline No individual income & $22(9.8)$ & $18(9.2)$ & $4(13.3)$ \\
\hline$\leqslant 2$ minimum salaries $\$$ & $47(20.9)$ & $41(21.0)$ & $6(20.0)$ \\
\hline 2-10 minimum salaries & $114(50.7)$ & $101(51.8)$ & $13(43.4)$ \\
\hline$>10$ minimum salaries & $42(18.6)$ & $35(18.0)$ & $7(23.3)$ \\
\hline Born in Rio & $169(75.1)$ & $147(75.4)$ & $22(73.3)$ \\
\hline Live in Rio & $163(72.4)$ & $144(73.8)$ & $19(63.3)$ \\
\hline \multicolumn{4}{|l|}{ Source of recruitment } \\
\hline Treatment centre 1 & $192(85.3)$ & $175(89.7)$ & $17(56.7)$ \\
\hline Treatment centre 2 & $28(12.4)$ & $20(10.3)$ & $8(26.7)$ \\
\hline Therapeutic community & $5(2.2)$ & $0(0)$ & $5(16.6)$ \\
\hline
\end{tabular}

Statistically significant differences between men and women (Chi-square/Fisher's exact test) in bold: ${ }^{*}$ Among those with stable partners, women co-habit less frequently $(P=0.016) ;{ }^{\top}$ Women tend to have been imprisoned or jailed less frequently $(P=0.009)$; ${ }^{\$}$ Minimum monthly salary approximately equal to R\$120.00 (then US\$105.00)

the patients (40 individuals) had never used illicit drugs, but only alcoholic beverages.

Crack use was reported significantly more frequently by women than by men, in both lifetime use $(P=0.034)$ and use in the last 6 months $(P=0.018)$. The same applies for amphetamine use in the last 6 months, confirming previous findings from other Brazilian studies ${ }^{17}$.

Levels of reported risky sexual behaviour were high in the sample. As shown in Table 2, most of the men $(75 \%)$ had had sexual relationships with commercial sex workers and over one-quarter $(27 \%)$ of them had exchanged money or drugs for sex during the 6 months preceding interview, behaviours far more common among men than women ( $P=0.000$ and $P=0.049$, respectively). On the other hand, women were significantly more frequently sexually engaged with IDUs $(P=0.020)$ and also received money or drugs for sex more often $(P=0.018)$.

Overall, levels of consistent condom use were very low, irrespectively of the nature of partnership, and for both vaginal and anal intercourse. The frequencies for 'sex usually under the influence' of both alcohol and drugs were also found to be high-over $63 \%$ for both sexes and (groups of) substances.

A lifetime history of hepatitis was reported by roughly $11-13 \%$ of the patients, which is consistent with the prevalence found for anti-HBC, a seromarker of HBV lifetime infection (Table 3). Such figures point to a moderate underestimation of lifetime hepatitis by the interviewees - even considering a history of non or olygo-symptomatic HBV infections - when we consider the additional toll imposed by infection with hepatitis $C$, which was found in roughly $6 \%$ of the sample.

A sizeable number of the interviewees, with a significantly higher proportion of women $(50 \%$ vs $23 \% ; P=0.002)$, reported current genitourinary symptoms, although figures for specific STIs assessed by the study are lower, at around $5 \%$ for chlamydia/gonorrhoea and syphilis infection, for both sexes (Table 3).

Two of the interviewees were found to be infected with HIV-1, both of them males. The first 
Table 2. Drug consumption, sexual behaviour and medical history characteristics of study population: drug users from inpatient units, Rio de Janeiro 1998

\begin{tabular}{|c|c|c|c|}
\hline Variables & $\begin{array}{l}\text { All }(n=225) \\
n(\%)\end{array}$ & $\begin{array}{l}\text { Men }(n=195) \\
n(\%)\end{array}$ & $\begin{array}{l}\text { Women } \\
(n=30) \\
n(\%)\end{array}$ \\
\hline Previously treated for drug use & $78(34.7)$ & $67(34.9)$ & $11(36.7)$ \\
\hline CAGE test positive & $141(62.7)$ & $123(65.4)$ & $18(60.0)$ \\
\hline \multicolumn{4}{|l|}{ Drug injection } \\
\hline Lifetime & $24(10.7)$ & $21(10.8)$ & $3(10.0)$ \\
\hline Last 6 months & $3(1.3)$ & $2(1.0)$ & $1(3.3)$ \\
\hline Cocaine injection (lifetime) & $22(9.8)$ & $20(10.3)$ & $2(6.7)$ \\
\hline \multicolumn{4}{|l|}{ Cocaine use } \\
\hline Lifetime & $168(74.7)$ & $144(73.8)$ & $24(80.0)$ \\
\hline Last 6 months & $150(66.7)$ & $130(66.7)$ & $20(66.7)$ \\
\hline \multicolumn{4}{|l|}{ Crack use } \\
\hline Lifetime & $29(12.9)$ & $21(10.8)^{1}$ & $8(26.7)^{1}$ \\
\hline Last 6 months & $13(5.8)$ & $8(4.1)^{2}$ & $5(16.7)^{2}$ \\
\hline \multicolumn{4}{|l|}{ Marijuana use } \\
\hline Lifetime & $163(72.4)$ & $139(71.3)$ & $24(80.0)$ \\
\hline Last 6 months & $108(48.0)$ & $93(47.7)$ & $15(50.0)$ \\
\hline \multicolumn{4}{|l|}{ Heroin use } \\
\hline Lifetime & $7(3.1)$ & $6(3.1)$ & $1(3.3)$ \\
\hline Last 6 months & $2(0.9)$ & $2(1.0)$ & $0(0)$ \\
\hline \multicolumn{4}{|l|}{ Amphetamine use } \\
\hline Lifetime & $43(19.1)$ & $36(18.5)$ & $7(23.3)$ \\
\hline Last 6 months & $10(4.4)$ & $6(3.1)^{3}$ & $4(13.3)^{3}$ \\
\hline \multicolumn{4}{|l|}{ Glue sniffing } \\
\hline Lifetime & $47(20.9)$ & $41(21.0)$ & $6(20.0)$ \\
\hline Last 6 months & $6(2.7)$ & $4(2.1)$ & $2(6.7)$ \\
\hline Sex with male homo/bisexuals (lifetime) & $85(37.8)$ & $75(38.5)$ & $10(33.3)$ \\
\hline Sex with IDU (lifetime) & $32(14.2)$ & $23(11.8)^{4}$ & $9(30.0)^{4}$ \\
\hline Sex with CSWs (lifetime) & $159(70.7)$ & $146(74.9)^{5}$ & $13(39.4)^{5}$ \\
\hline Sex with HIV+ person(s) (lifetime) & $5(2.2)$ & $5(2.6)$ & $0(0)$ \\
\hline Sex for money/drugs, last 6 months & $52(23.1)$ & $40(20.5)^{6}$ & $12(40.0)^{6}$ \\
\hline Vaginal & $31 / 50(62.0)$ & $20 / 38(52.6)$ & $11(91.7)$ \\
\hline Unprotected ${ }^{*}$ & $15(48.4)$ & $8(40.0)$ & $7(63.6)$ \\
\hline Anal & $31 / 51(60.8)$ & $27 / 39(69.2)$ & $4(33.3)$ \\
\hline Unprotected ${ }^{*}$ & $17(54.8)$ & $15(55.6)$ & $2(50.0)$ \\
\hline Gave money/drugs for sex, last 6 months & $55(24.4)$ & $52(26.7)^{7}$ & $3\left(\mathbf{1 0 . 0 ) ^ { 7 }}\right.$ \\
\hline \multicolumn{4}{|l|}{ Sex with stable partners, last 6 months } \\
\hline Vaginal & $153(68.0)$ & $132(67.7)$ & $21(70.0)$ \\
\hline Unprotected ${ }^{*}$ & $138(90.2)$ & $118(89.4)$ & $20(95.2)$ \\
\hline Anal & $56(24.9)$ & $45(23.1)$ & $11(36.7)$ \\
\hline Unprotected ${ }^{*}$ & $51(91.1)$ & $41(91.1)$ & $10(90.9)$ \\
\hline \multicolumn{4}{|l|}{ Sex with casual partners, last 6 months } \\
\hline Vaginal & $98(43.6)$ & $83(42.6)$ & $15(50.0)$ \\
\hline Unprotected ${ }^{*}$ & $80(81.6)$ & $68(81.9)$ & $12(80.0)$ \\
\hline Anal & $52(23.1)$ & $47(24.1)$ & $5(16.7)$ \\
\hline Unprotected* & $40(76.9)$ & $35(74.5)$ & $5(100.0)$ \\
\hline Sex usually under influence of alcohol & $174(77.3)$ & $148(75.9)$ & $26(86.7)$ \\
\hline Sex usually under influence of drugs & $142(63.1)$ & $122(62.6)$ & $20(66.6)$ \\
\hline Lifetime history of hepatitis & $27(12.0)$ & $23(11.8)$ & $4(13.3)$ \\
\hline Lifetime history STD & $97(42.5)$ & $86(44.1)$ & $11(36.7)$ \\
\hline \multicolumn{4}{|l|}{ Any genitourinary symptoms } \\
\hline Lifetime & $172(76.4)$ & $143(73.3)^{8}$ & $29(96.7)^{8}$ \\
\hline Current & $59(26.2)$ & $44(22.6)^{8}$ & $15(50.0)^{8}$ \\
\hline Previous HIV test & $83(36.9)$ & $62(31.8)$ & $21(70.0)$ \\
\hline
\end{tabular}

Statistically significant differences between men (M) and women (W) (Chi-square/Fisher's exact test) in bold: higher rates of consumption of crack cocaine among $W$ than $M:{ }^{1}$ Lifetime: $P=0.034 ;{ }^{2}$ Last 6 months: $P=0.018$; ${ }^{3}$ Higher rates of consumption of amphetamines among $W$ than $\mathrm{M}$ in last 6 months: $P=0.031$; ${ }^{4}$ Higher proportion of $W$ than $M$ having had sex with injecting drug user (IDU) (lifetime): $P=0.020$; ${ }^{5}$ Higher proportion of $M$ than $W$ having had sex with commercial sex workers (CSWs) (lifetime): $P=0.000$; ${ }^{6}$ Higher proportion of $W$ than $M$ having exchanged sex for money/drugs, last 6 months: $P=0.018$; ${ }^{7}$ Higher proportion of $\mathrm{M}$ than $\mathrm{W}$ gave money/drugs in exchange for sex in last 6 months: $P=0.049$; ${ }^{8}$ Higher rates of genitourinary symptoms among $W$ than $M$ : lifetime, $P=0.005$; current, $P=0.002$; *Unprotected=proportion of reported inconsistent or no condom use among people having these kind of partnerships (i.e. denominator) 
Table 3. Point prevalences (\%) for different infections in the sample: drug users from inpatient units, Rio de Janeiro 1998

\begin{tabular}{|c|c|c|c|}
\hline \multirow[b]{2}{*}{ Infectious agent } & \multicolumn{3}{|c|}{ Prevalences (\%) } \\
\hline & All $(n=225)$ & Men $(n=195)$ & $\begin{array}{l}\text { Women } \\
(n=30)\end{array}$ \\
\hline HIV & 0.9 & 1.0 & 0.0 \\
\hline $\mathrm{HBV}$ (past infection-anti-HBC) & 14.7 & 13.8 & 20.0 \\
\hline HBV (current infection-HBsAg) & 0.4 & 0.5 & 0.0 \\
\hline HCV (any infection) & 5.8 & 5.6 & 6.7 \\
\hline Treponema pallidum & 5.3 & 4.6 & 10.0 \\
\hline Chlamydia trachomatis/Neisseria gonorrhoene & $4.7^{*}$ & 4.7 & 4.3 \\
\hline
\end{tabular}

*192 samples evaluated (169 in men and 23 in women)

Table 4. Prevalence (\%) of sexually transmitted infections/blood-borne infections (STIS/BBIs) according to selected characteristics for which significant associations between these characteristics and the biological markers were found, Rio de Janeiro 1998

\begin{tabular}{|c|c|c|c|}
\hline & Hepatitis C & Syphilis & $\begin{array}{l}\text { Chlamydia or } \\
\text { gonorrhoea* }\end{array}$ \\
\hline \multicolumn{4}{|l|}{ Age } \\
\hline$<25$ years & $3.5 \%(2 / 57)$ & $1.8 \%(1 / 57)$ & $12.5 \%(6 / 48)$ \\
\hline $25-29$ years & $6.5 \%(3 / 46)$ & $6.5 \%(3 / 46)$ & $5.0 \%(2 / 40)$ \\
\hline \multirow[t]{2}{*}{$30+$ years } & $6.6 \%(8 / 122)$ & $6.6 \%(8 / 122)$ & $1.0 \%(1 / 104)$ \\
\hline & NS & NS & $P=0.002$ \\
\hline \multicolumn{4}{|l|}{ Education } \\
\hline$<8$ years & $4.9 \%(5 / 103)$ & $5.8 \%(6 / 103)$ & $4.6 \%(4 / 88)$ \\
\hline \multirow[t]{2}{*}{$>8$ years +} & $6.6 \%(8 / 122)$ & $4.9 \%(6 / 122)$ & $4.8 \%(5 / 104)$ \\
\hline & NS & NS & NS \\
\hline \multicolumn{4}{|c|}{ Ever injected drugs ${ }^{+}$} \\
\hline Yes & $33.3 \%(8 / 24)$ & $0.0 \%(0 / 24)$ & $4.5 \%(1 / 22)$ \\
\hline \multirow{3}{*}{ No } & $2.5 \%(5 / 201)$ & $6.0 \%(12 / 201)$ & $4.7 \%(8 / 170)$ \\
\hline & $\mathrm{OR}=19.6(5.7-67.0)$ & NA & NS \\
\hline & $P=0.000$ & & \\
\hline \multicolumn{4}{|c|}{ Ever injected cocaine } \\
\hline Yes & $36.4 \%(8 / 22)$ & $0.0 \%(0 / 22)$ & $5.0 \%(1 / 20)$ \\
\hline \multirow[t]{3}{*}{ No } & $2.5 \%(5 / 203)$ & $5.9 \%(12 / 203)$ & $4.7 \%(8 / 172)$ \\
\hline & $\mathrm{OR}=22.6(6.5-78.3)$ & NA & NS \\
\hline & $P=0.000$ & & \\
\hline \multicolumn{4}{|c|}{ Ever used amphetamines } \\
\hline Yes & $14.0 \%(6 / 43)$ & $0.0 \%(0 / 43)$ & $5.7 \%(2 / 35)$ \\
\hline \multirow[t]{3}{*}{ No } & $3.9 \%(7 / 182)$ & $6.6 \%(12 / 182)$ & $4.5 \%(7 / 157)$ \\
\hline & $\mathrm{OR}=4.1(1.3-12.8)$ & NA & NS \\
\hline & $P=0.021$ & & \\
\hline \multicolumn{4}{|c|}{ Ever used tranquillizers } \\
\hline Yes & $11.1 \%(10 / 90)$ & $3.3 \%(3 / 90)$ & $5.0 \%(4 / 80)$ \\
\hline \multirow[t]{3}{*}{ No } & $2.2 \%(3 / 135)$ & $6.7 \%(9 / 135)$ & $4.5 \%(5 / 112)$ \\
\hline & $\mathrm{OR}=5.5(1.5-20.6)$ & NS & NS \\
\hline & $P=0.005$ & & \\
\hline \multicolumn{4}{|c|}{$>1$ male sexual partner in last 6 months } \\
\hline Yes & $8.1 \%(1 / 32)$ & $13.5 \%(5 / 37)$ & $9.7 \%(3 / 31)$ \\
\hline \multirow{3}{*}{ No } & $5.3 \%(10 / 188)$ & $3.7 \%(7 / 188)$ & $3.7 \%(6 / 16)$ \\
\hline & NS & $\mathrm{OR}=4.0(1.2-13.5)$ & NS \\
\hline & & $P=0.03$ & \\
\hline \multicolumn{4}{|c|}{ Current genitourinary symptoms $s^{\ddagger}$} \\
\hline Yes & $4.7 \%(2 / 43)$ & $4.7 \%(2 / 43)$ & $12.8 \%(5 / 39)$ \\
\hline \multirow[t]{4}{*}{ No } & $5.9 \%(9 / 152)$ & $4.6 \%(7 / 152)$ & $2.3 \%(3 / 130)$ \\
\hline & NS & NS & $\mathrm{OR}=6.2(1.4-$ \\
\hline & & & $27.4)$ \\
\hline & & & $P=0.007$ \\
\hline \multicolumn{4}{|c|}{ Source of income mainly illegal } \\
\hline & $3.1 \%(1 / 32)$ & $6.6 \%(2 / 33)$ & $18.5 \%(5 / 27)$ \\
\hline \multirow{4}{*}{ No } & $6.2 \%(12 / 193)$ & $5.2 \%(10 / 193)$ & $2.4 \%(4 / 165)$ \\
\hline & NS & NS & $\mathrm{OR}=9.1(2.3-$ \\
\hline & & & $36.7)$ \\
\hline & & & $P=0.003$ \\
\hline
\end{tabular}

*192 drug users; OR (95\% CI) for dichotomous variables; "Tranquillizer use not as part of a therapeutic regimen; ${ }^{\mathrm{t}} \mathrm{Men}$ only (not whole sample). For dichotomous variables, Chi-square or Fisher's exact tests were used; for categorical variables with more than 2 categories, the Mantel-Haenszel Chi-square test for trend was used; for continuous variables, the Kruskal-Wallis test for means (Chi-square approximation) was used. NS=not significant 
Table 5. Prevalence of hepatitis B according to selected characteristics among 225 drug users, Rio de Janeiro 1998 [n=225 (195 men, 30 women)]

\begin{tabular}{|c|c|c|c|c|c|}
\hline & \multirow{2}{*}{$\begin{array}{r}\text { Prevalence } \\
\text { hepatitis B } \\
\text { (anti-HBc) }\end{array}$} & \multicolumn{2}{|c|}{ Univariate analysis } & \multicolumn{2}{|c|}{ Multivariate analysis } \\
\hline & & OR & $P$ value & Adjusted OR & $P$ value \\
\hline \multicolumn{6}{|l|}{ Age } \\
\hline$<25$ years & $3.5 \%(2 / 57)$ & 1.0 & 0.003 & 1.0 & \\
\hline $25-29$ years & $13.0 \%(6 / 46)$ & $4.1(0.8-21.5)$ & & $4.89(0.87-27.55)$ & \\
\hline $30+$ years & $20.5 \%(25 / 122)$ & $7.1(1.6-31.1)$ & & $8.69(1.78-42.52)$ & $0.0620^{*}$ \\
\hline \multicolumn{6}{|l|}{ Education } \\
\hline$<8$ years & $21.4 \%(22 / 103)$ & $2.7(1.3-6.0)$ & 0.009 & $3.70(1.58-8.69)$ & 0.0027 \\
\hline$>8$ yearst & $9.0 \%(11 / 122)$ & & & & \\
\hline \multicolumn{6}{|c|}{ Ever injected drugs } \\
\hline Yes & $29.2 \%(7 / 24)$ & $2.8(1.1-7.3)$ & 0.059 & $3.69(1.24-10.99)$ & 0.019 \\
\hline No & $12.9 \%(26 / 201)$ & & & & \\
\hline \multicolumn{6}{|c|}{ Ever injected cocaine } \\
\hline Yes & $31.8 \%(7 / 22)$ & $3.2(1.2-8.5)$ & 0.026 & $\dagger$ & - \\
\hline No & $12.8 \%(26 / 203)$ & & & & \\
\hline \multicolumn{6}{|l|}{ CAGE test } \\
\hline Positive & $17.7 \%(25 / 141)$ & $2.1(0.9-5.2)$ & 0.091 & $1.12(0.42-3.00)$ & 0.81 \\
\hline Negative & $9.2 \%(7 / 76)$ & & & & \\
\hline
\end{tabular}

*Test for trend; "'ever injected drugs' but not 'ever injected cocaine', was entered in the final model due to the fact the two practically (exception made to 2 cases) overlap

one had never injected drugs, had never had sex with women and had a history of unprotected sex with male homo/bisexuals, and with (male) commercial sex workers. The second one had a lifetime history of cocaine injection, but stopped injecting in 1983, the same year he reported having shared syringes with an HIV+ person. He also reported having had lifetime sexual relations with both men and women, including unprotected sex with people he knew to be HIV-infected.

Bivariate statistically significant associations between sociodemographic and clinical variables and BBIs and STIs are presented in Table 4 and Table 5 (for hepatitis B).

Chalmydia trachomatis/N. gonorrhoeae infection was found to be associated with younger age $(P=0.003) ; \quad$ current genitourinary symptoms $(\mathrm{OR}=6.2 ; P=0.007)$ and a mainly illegal source of income (OR=9.1; $P=0.003$ ). Hepatitis $C$ was found to be associated with a history of ever having injected any drug $(\mathrm{OR}=19.6 ; P=0.000)$, and with each one of the injected drugs $(\mathrm{OR}=22.6 ; P=0.000$, for cocaine; $\mathrm{OR}=4.1 ; P=0.0021$, for amphetamines; and $O R=5.5 ; P=0.005$, for tranquillizers).

Prevalence of hepatitis $B$ (anti-HBc) was found to be associated with increasing age $(P=0.003)$, lower levels of education (OR=2.7; $P=0.009)$, and ever having injected cocaine $(\mathrm{OR}=3.2 ; P=0.026)$, with a borderline association $(P=0.059)$ with 'ever having injected drugs' in bivariate analyses. Associations were further evaluated by multiple logistic regression that shows a borderline significant trend for age, and highlights lower educational level as an independent risk factor ( $A O R=3.70 ; P=0.0027)$. Due to the fact that for only 2 persons a lifetime history of injection of 'any drug' and of cocaine were not concomitant, only 'ever having injected drugs' was entered in the final logistic regression, and was also found to be an independent risk factor for HBV infection ( $A O R=3.69 ; P=0.019)$ (Table 5).

\section{DISCUSSION}

The relationship between alcohol and drug consumption and risky behaviour is quite complex and bidirectional, i.e. psychoactive substances modulate behaviour, but it is also the case that people with certain lifestyles seek specific mindaltering substances as a way to enhance/reinforce pre-existing behaviours ${ }^{19}$.

The association of injected drugs with the risk of HIV and many other infections, both secondary to the sharing of injection equipment and to the effects of the injected drugs upon sexual attitudes and behaviours, has been clearly established $11,20,21$. Mounting evidence also points to the association of crack cocaine consumption with the spread of HIV/AIDS and syphilis, through the enhancement

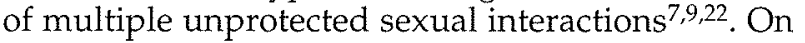
the other hand, findings are contradictory and/or fragmentary respecting users of drugs other than crack cocaine or injected cocaine powder ${ }^{19,23,24}$.

The drug and alcohol users assessed here, the vast majority of whom were non-injecting cocaine or crack users, had low/moderate infection rates for all the pathogens/infections under analysis, grossly comparable with data obtained in Brazil in the so-called 'general population', with the 
exception of $\mathrm{HCV}$ infection $3,25,26$. As the number of active and/or former injectors in our sample was quite small (24) and the number of recipients of blood or blood components negligible (data not shown) few people seemed to be parenterally exposed to BBI.

Our sample comprised only inpatients who voluntarily agreed to be treated for their addictive habits. Non-injecting cocaine users (including powder cocaine snorters and-relatively fewcrack cocaine smokers) had been assessed before by only one Brazilian survey, in Rio de Janeiro, that found a point seroprevalence of $8.6 \%$ (no CI was provided), but this sample was exclusively recruited from the streets of low-income neighbourhoods, and included former IDUs ${ }^{27}$. The population here under analysis voluntarily adhered to drug treatment centres' strictly abstinenceoriented rules and often waited for long periods to be admitted to the over-subscribed drug treatment centres of Rio (one-third of them, for at least a second time).

Most of the interviewees reported having had sex with IDUs, gay men and/or commercial sex workers, and having themselves been paid for sex, populations with relatively high levels of HIV, STIs and BBIs ${ }^{1-7,11,25,26,28}$, and the vast majority of sexual relationships in which the interviewees engaged were unprotected, regardless of the type of partnership.

The association between CT/NG infection and younger age is consistent with the literature on the epidemiology of these 2 infections, particularly for chlamydial infection which commonly occurs significantly more frequently at younger ages ${ }^{29}$. The association between CT/NG infection and current urogenital symptoms reflects the rôle of such infections in the aetiology of urethritis and other clinical syndromes, especially among men, of which they are frequently symptomatic. On the other hand, current urogenital symptoms, especially among female interviewees, were significantly more frequent than actual levels of STIs detected by laboratory analysis, likely due to other causes of vaginal discharge (e.g. Candida albicans, Trichomonas vaginalis).

Given the relatively high proportion of interviewees reporting having received money or drugs for sex, frequently unprotected, it is not surprising to find an association between mainly illegal income sources and CT/NG infection. Illegal sources of income also included involvement in drug trafficking and other criminal offences, but the low figures for CT/NG preclude a closer evaluation of the putative association of other aspects of such risky lifestyles with STD infection. Syphilis was associated, as expected in a sample with low overall levels of consistent condom use, with a higher number of sexual partners in the last 6 months.

The association between HBV infection and lower school attainment may be a proxy for lower socioeconomic levels, poor standards of hygiene ${ }^{30}$, lower standards of medical and dental care ${ }^{31}$, and/ or lack of access to hepatitis B vaccination, which is not yet available free of charge in Brazil. A history of ever having injected illicit drugs (all injectable drugs and cocaine) was associated with higher levels of hepatitis $B$ infection, underlining the relevance of parenteral exposure. Cocaine injection - the drug of choice of almost all former and current injectors in the sample-seems to put IDUs at a particular risk for BBIs, due to the 'binge' pattern of self-administration ${ }^{32}$.

The association of hepatitis $\mathrm{C}$ with a history of ever having injected any drug, and with each one of the injected drugs, confirms previous findings of a prominent rôle played by parenteral exposure in the transmission of this pathogen ${ }^{3}$. This probably explains why the sample under analysis presents a seroprevalence for HCV roughly twice as high as that found in a previous study carried out among blood donors in Rio de Janeiro $(2.7 \%)^{33}$.

Preventive interventions carried out with drug users have many public health implications since:

(a) drug using patterns are very mutable, and transitions to more risky patterns are common, as are relapses from safer behaviours, including abstinence ${ }^{34,35}$;

(b) drug-using patterns are frequently so interwoven with risky lifestyles that the latter must be addressed in order to bring about behavioural change and halt the spread of HIV and other STIs ${ }^{19}$;

(c) the relatively frequent interaction between 'low-risk' and 'high-risk' drug users in the drug scene could putatively put the former under increased risk for STIs secondary to unprotected sex, as described in other contexts ${ }^{36}$.

In conclusion, the relatively low infection rates found in this study should not be viewed with complacency, since, given the high levels of reported sexual risk behaviours, particularly involvements in commercial sex, interventions to prevent further infection through injection drug use and unprotected sex are clearly necessary. As such, drug treatment centres may represent an important opportunity to gain access to such at-risk populations, which are usually hard to reach. These opportunities seem in general to have been lost in Brazil ${ }^{10}$, where preventive programmes are seldom carried out in drug abuse treatment centres. Keeping in mind that drug users frequently drop out before the conclusion of drug treatment programmes and/or relapse into former patterns of drug abuse ${ }^{34}$, preventive initiatives such as the one described here should be viewed as 'golden windows', and implemented urgently in as many centres as possible.

Acknowledgements: The project was core funded by the Brazilian Ministry of Health and the Oswaldo 
Cruz Foundation which is a UNAIDS Collaborative Centre, with additional funds from the Medical Research Council of Canada (MRCC) and the Brazilian National Research Council (CNPq). Dr Bastos was a recipient of a MRCC/CNPq scholarship at Laval University (July/August 1998), and is currently a 'Rio de Janeiro State scientist' (FAPERJ). FIB, MGM and CFTY are researchers of CNPq. Michel Alary is the recipient of a research scholarship from Fondis de recherche en santé du Québec (no. 970097).

Thanks are due to Sergio Oliveira for biological sample processing; Kátia Coutinho for assistance with questionnaire design; Julie Jacques and Caty Blanchette for assistance in statistical analyses; $M$ Lourdes Oliveira for comments on the manuscript; Wulmar Bastos Jr and the interviewers for their work in the field; and the staff and patients of the drug treatment centres who took part in the project.

\section{References}

1 Bastos FI, Strathdee AS, Derrico M, Pina F. Drug use and the spread of HIV/AIDS in South America and the Caribbean. Drug Educ Prev Polic 1999;6:29-50

2 Carvalho HB, Mesquita F, Massad E, et al. HIV and infections of similar transmission patterns in a drug injectors community of Santos, Brazil. J Acquir Immune Defic Syndr Hum Retrovirol 1996;12:84-92

3 Oliveira MLA, Bastos FI, Telles PR, et al. Prevalence and risk factors for HBV, HCV and HDV infections among injecting drug users from Rio de Janeiro, Brazil. Braz J Med Biol Res 1999;32:1107-14

4 Andrade T, Dourado I, Galvão-Castro B. Associations among HTLV-1, HTLV-II and HIV in injecting drug users in Salvador, Brazil. I Acquir Immune Defic Syndr Hum Retrovirol 1998;18:186-7

5 Dourado I, Andrade T, Galvão-Castro B. HTLV-I in northeast Brazil: differences for male and female injecting drug users. I Acquir Immune Defic Syndr Hum Retrovirol 1998; 19:426-9

6 Dourado I, Andrade T, Carpenter CL, Galvão-Castro B. Risk factors for human $\mathrm{T}$ cell lymphotropic virus type I among injecting drug users in northeast Brazil: possibly greater efficiency of male to female transmission. Mem Inst Oswaldo Cruz 1999;94:13-18

7 Szwarcwald CL, Bastos FI, Gravato N, Lacerda R, Chequer $\mathrm{PN}$, Castilho EA. The relationship of illicit drug consume to HIV-infection among commercial sex workers (CSWs) in the city of Santos, São Paulo, Brazil. Int J Drug Polic 1998;9:427-36

8 Massad E, Rozman M, Azevedo RS, et al. Seroprevalence of $\mathrm{HIV}, \mathrm{HCV}$ and syphilis in Brazilian prisoners: preponderance of parenteral transmission. Eur / Epidemiol 1999;15: 439-45

9 Fullilove MT, Fullilove RE. Intersecting epidemics. Black teen crack use and sexually transmitted diseases. J Am Med Woman Assoc 1989;44:146-53

10 Bastos Jr WS, Telles PR, Bastos FI. O tratamento da dependência química e a prevenção da AIDS [The treatment of chemical dependency and AIDS prevention] (Abstract). II Seminário Internacional sobre as Toxicomanias [II International Seminar on Drug Abusel, Rio de Janeiro, Brazil, 1996:28
11 Telles PR, Bastos FI, Guydish J, et al. Risk behaviors and HIV seroprevalence among IDUs in Rio de Janeiro, Brazil. AIDS 1997;11:S35-44

12 Lampe E, Oliveira JM, Pereira JL, Saback FL, Yoshida CFT, Niel C. Hepatitis $G$ virus (GBV-C) infection among Brazilian patients with chronic liver disease and blood donors. Clin Ding Virol 1998;9:1-7

13 Dean AD, Dean JA, Burton AH, Dicker RC. Epi Info, Version 6: A Word Processing, Database, and Statistics for Epidemiology on Microcomputers. Atlanta: Centers for Disease Control and Prevention, 1990

14 SAS Institute Inc. SAS User's Guide, version 6, 4th edn. Cary, NC: SAS Institute, 1991

15 Fundação Instituto Brasileiro de Geografia e Estatística (FIBGE). Censo Demográfico 1991 [Brazilian National Census 1991]. Rio de Janeiro: FIBGE, 1991

16 Fundação Instituto Brasileiro de Geografia e Estatística (FIBGE). Newosletter 1999; 57 (June/July)

17 Bastos FI, Carlini-Cotrim B. O consumo de substâncias psicoativas entre os jovens brasileiros: dados, danos \& algumas propostas [Drug consume by Brazilian youth: data and prospects for prevention]. In: Jovens Acontecendo nas Trilhas das políticas públicas, Vol. II. Brasilia: Comissão Nacional de População e Desenvolvimento, 1998:645-69

18 Masur J, Monteiro MG. Validation of the 'CAGE' alcoholism screening test in a Brazilian psychiatric inpatient hospital setting. Braz J Med Biol Res 1983;16:215-18

19 Des Jarlais DC. Intoxications, intentions and disease preventions [Editorial]. Sex Transm Dis 1997;24:320-1

20 Des Jarlais DC, Stimson G, Hagan $H$, et al. Emerging infectious diseases and the injection of illicit psychoactive drugs. Curr Issues Pub Health 1996;2:1320-7

21 Strathdee SA, van Ameijden E, Mesquita F, Wodak A, Rana $S$, Vlahov D. Can HIV epidemics among injection drug users be prevented? AIDS 1998;12:S71-9

22 Edlin BR, Irwin KL, Faruque $S$, et al. Intersecting epidemics-crack cocaine and HIV infection among inner-city young adults. The Multicenter Crack Cocaine and HIV Infection Study Team. N Engl J Med 1994;331: $1422-7$

23 Shafer M-A, Hilton JF, Ekstrand $M$, et al. Relationship between drug use and sexual behaviors and the occurrence of sexually transmitted diseases among high-risk male youth. Sex Transm Dis 1993;20:307-13

24 Fortenberry JD, Orr DP, Katz BP, Brizendine EJ, Blythe MJ. Sex under influence: a diary self-report study of substance use and sexual behavior among adolescent women. Sex Transm Dis 1997;24:313-19

25 Bastos FI, Telles PR, Castilho EA, Barcellos C. A epidemia de AIDS no Brasil [The AIDS epidemic in Brazil]. In: Minayo CS, ed. Os muitos brasis: Sanide e população na década de 80. São Paulo/Rio de Janeiro: Hucitec \& ABRASCO, 1995:245-68

26 Lowndes CM. Doenças sexualmente transmissiveis nas mulheres [Sexually transmitted diseases in women]. In: Giffin K, Costa S, eds. Questöes de Sauide Reprodutiva. Rio de Janeiro: Ed. Fiocruz, 1999:253-80

27 Inciardi JA, Surratt $H$, Telles $\mathrm{P}$, et al. Risks for HIV-1 infection and seropositivity rates among cocaine users in Rio de Janeiro, Brazil [Poster Th.C.425]. XI International Conference on AIDS, Vancouver, 1996

28 Souza CTV, Bastos FI, Lowndes CM, et al. Perception of vulnerability to HIV infection in a cohort of homosexual/ bisexual men in Rio de Janeiro, Brazil. AIDS Care 1999;11:567-79

29 Mangione-Smith R, O'Leary J, McGlymn EA. Health and cost-benefits of chlamydia screening in young women. Sex Transm Dis 1999;26:309-16 
30 Salleras L, Bruguera M, Vidal J, et al. Prevalence of hepatitis $B$ markers in the population of Catalonia (Spain). Rationale for universal vaccination of adolescents. Eur J Epidemiol 1992;8:640-4

31 Passos AD, Gomes UA, Figueiredo JF, et al. Influence of migration on the prevalence of serologic hepatitis $B$ markers in a rural community. 2. Comparative analysis of various characteristics of the population studied [in Portuguese]. Rev Saude Publica 1993;27:36-42

32 Anthony JC, Vlahov D, Nelson KE, Cohn S, Astemborski J, Solomon L. New evidence on intravenous cocaine use and the risk of infection with human immunodeficiency virus type 1. Am J Epidemiol 1991;134:1175-89

33 Vanderborght BO, Reis AMM, Rouzerè CD, et al. Prevalence of anti-hepatitis $C$ virus in the blood donor population of Rio de Janeiro. Vox Sang 1993;65:122-5
34 Van Ameijden EJC, van den Hoek JAR, Hartgers C, Coutinho RA. Risk factors for the transition from noninjection to injection drug use and accompanying AIDS risk behavior in a cohort of drug users. Am $J$ Epidemiol 1994;139:1153-63

35 Dunn J, Laranjeira RR. Transitions in the route of cocaine administration-characteristics, direction and associated variables. Addiction 1999;94:813-24

36 Montoya ID, Atkinson JS. Determinants of HIV seroprevalence rates among sites participating in a community-based study of drug users. I Acquir Immune Defic Syndr Hum Retrovirol 1996;13:169-76

(Accepted 20 January 2000) 